УДК $351.78: 008$

COBISS.SR-ID 513529013

https://doi.org/10.18485/fb_godisnjak.2019.8

\title{
КОНЦЕПТ СТРАТЕШКЕ КУЛТУРЕ У СТУДИЈАМА БЕЗБЕДНОСТИ
}

\author{
Душан Кесић", студент докторских студија \\ Универзитет у Београду, Факултет безбедности
}

dusankesic9@gmail.com 



\section{КОНЦЕПТ СТРАТЕШКЕ КУЛТУРЕ У СТУДИЈАМА БЕЗБЕДНОСТИ}

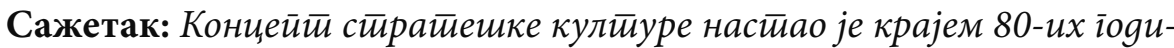
на 20. века. Аутиор који је уйемељио овај концейти у науци међународних оgноса, Џек Снајgер, уйотиребио је конщейй стиратешке кулитуре како би

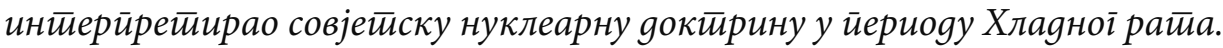

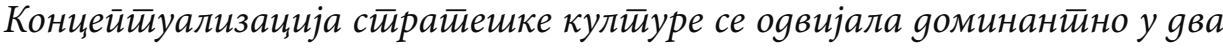
иеоријска ирристиуйа сииудија безбеgностии, реализму и социјалном кон-

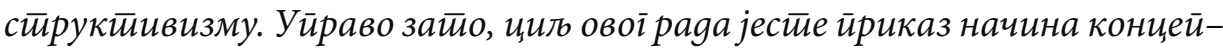

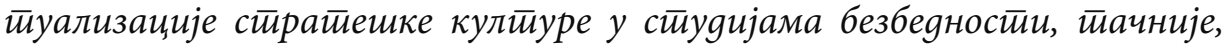
у оквиру школа реализма и социјалног констирукииивизма. Реализачија овоі ициь йодразумева йокушај gа се ирикажу најрелеванитнији налази

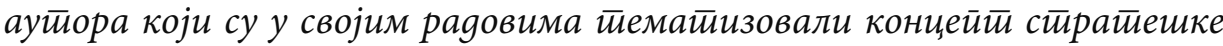

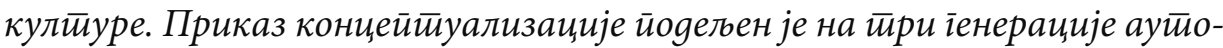
ра, gок раяови ауйора йрве и тиреће іенерације, Колина Греја и Алистера Џонстиона йреgстиављају „језіро“ метиоgолошких сйореюа у вези са кон-

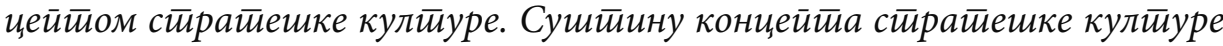

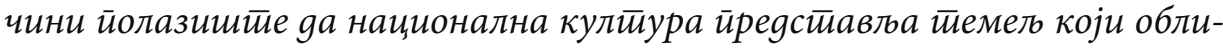

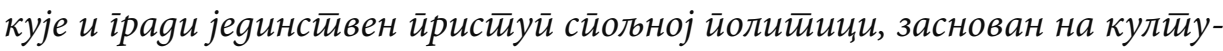
рално уйемельеном ӣоиману ратиа и уйотиребе силе.

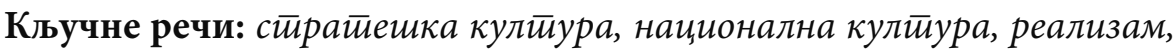
сочијални констируктиивизам. 


\section{Увод}

Мирољубиво окончање Хладног рата и успон хегемона у потпуности је уздрмао претпоставке реалиста о равнотежи моћи као фундаменталном обрасцу међународне политике. Наиме, неореализам почива на схватању да безбедност представља примарни циљ у стању анархичног међународног система. Само уколико је опстанак обезбеђен, државе могу тежити и другим циљевима, као што су мир, профит и моћ. Поред тога, кључна претпоставка Кенета Волца гласи: „Структура међународне политике је стална, обрасци се враћају, а догађаји бескрајно понављају“ (Waltz, 1979: 66 -79). Враћање истог, у виду успостављања равнотеже моћи, фундаментални је образац међународне политике према неореализму. ${ }^{31}$ Поред мирољубивог окончања Хладног рата, неореализам није могао да објасни нити предвиди расформирање Варшавског пакта и амбивалентно спољнополитичко деловање Народне Републике Кине током овог периода.

Крајем 80-их година 20. века, паралелно са утемељењем неореализма, у оквирима реалистичког приступа развијен је концепт стратешке културе, као одговор на акултуралну и аисторијску перспективу неореализма. Концепт стратешке културе развио је Џек Снајдер (Jack L. Snyder), за потребе интерпретирања совјетске нуклеарне доктрине. Снајдер посматра историју, традицију, културу и филозофију једне нације као фундаменталне факторе у изградњи и формирању специфичног приступа питањима рата и употребе силе.

Поред представника реализма, преглед становишта о концепту стратешке културе обухватиће и представнике социјалног конструктивизма. Овај теоријски приступ доживљава свој убрзани развој по окончању Хладног рата. Истина о друштвеној стварности за конструктивисте не садржи само једно, универзално и непроменљиво знање, већ постоји више могућих перспектива интерпретације стварности, у чијој основи су идеје, као матрица кроз коју не само да посматрамо свет око себе, него га и стварамо. (Enloe \& Zalewski, 1995: 299). Социјални конструктивисти међународне односе тумаче са превасходно идеалистичког, уместо ма-

31 Појам политичке структуре Волц (Kenneth Waltz) дефинише на основу три принципа: принцип организације, принцип спецификације функција и принцип дистрибуције моћи (Waltz, 1979: 88). Како међународна политика нема јасно дефинисан поредак и организацију, њен принцип организације је анархија. Јединице система се разликују према способностима (моћи), али не и према функцији. Све државе извршавају сличне задатке и теже сличним циљевима (1979: 89-96). Иако су способности (моћи) којима државе располажу њихова карактеристика, дистрибуција моћи међу јединицама није, она је системски концепт (1979: 97-98). На основу наведених критеријума, он утврђује да је међународни систем анархичан, али и да су све државе функционално сличне (примарно теже опстанку). 
теријалистичог аспекта и истичу да друштвена стварност не представља објективну категорију (Weber, 2010).

Александар Вент (Alexander Wendt) је идентификовао две основне карактеристике социјалног конструктивизма: 1. структура људских односа одређена је првенствено заједничком идејом, а не материјалним факторима; 2. идентитет и интереси актера нису одређени природом појаве, него су изграђени на тој заједничкој идеји (Wendt, 1999: 1). Дакле, неореалистичком материјализму социјални конструктивизам супротставља идеје и идентитете друштвених актера, као кључни елемент у изградњи природе анархије и међународне политике.

Конструктивистичка перспектива стратешке културе према Џонстону (Alastair Ian Johnston) подразумева супротстављање аисторијским и тзв. „објективним“ варијаблама, у виду материјалних капацитета и технологије. Оне уживају секундарни значај, јер бивају интерпретиране кроз „сочива“ стратешке културе, што значи да су стратешки избори мање зависни од промене у објективном стратешком окружењу, будући да историјски укорењене стратешке преференције одређују одговор на ове варијабле (Johnston, 1995).

Циљ овог рада представља покушај приказа најзначајнијих налаза аутора, представника школа реализма и социјалног конструктивизма, који су у својим радовима тематизовали концепт стратешке културе. Концептуализација стратешке културе биће представљена кроз приказ три генерације истраживача, које је дефинисао Алистер Џонстон. Прва генерација се јавља крајем 80-их година и представља покушај да се објасни зашто Американци и Совјети имају другачију стратегију у „нуклеарном добу“. Наведене разлике су објашњене дубоко укорењеним историјским искуством, политичком културом, географијом и другим варијаблама. Друга генерација настаје средином 80-их година, такође фокусирана на суперсиле, али из грамшијевске перспективе. Овај приступ препознаје могућност несклада стратешко-културалног дискурса и оперативних доктрина, јер дискурс бива злоупотребљен од стране елите како би ојачао хегемонију владајуће елите и њен ауторитет да дефинише оперативне доктрине. Трећа генерација настаје средином 90-их и представља строжи концептуални и методолошки приступ, са фокусом на зависну варијаблу (стратешко понашање), како би се успоставио поуздан и исправан начин за тестирање утицаја стратешке културе (Johnston, 1995).

Неколико радова аутора прве и треће генерације, Колина Греја (Colin S. Grey) и Алистера Џонстона, представља срж спорења у вези са методолошким приступом концепту стратешке културе. Греј тежи да укаже на 
културни контекст понашања, док Џонстон концепту приступа позитивистички, са циљем да успостави јасну узрочно-последичну везу између културних претпоставки и понашања. На трагу ових методолошких спорења развијала се критика аутора прве и треће генерације аутора.

\section{Настанак концепта стратешке културе}

Иако је култура дуго времена оспоравана као потенцијално корисна перспектива за анализу стратешког размишљања и деловања, крајем 70их година уследило је њено увођење у науку међународних односа. Препознавање значаја културне димензије међународних односа резултат је потребе да се реалистичким акултуралним и аисторијским објашњењима придода историјска и културна перспектива. Управо се концепт стратешке културе јавља као форма имплементације културе у проучавање међународних односа. Овај концепт претпоставља да специфичне карактеристике националне културе једне државе воде јединственом приступу спољној политици, заснованом на културално утемељеном поимању рата. Дакле, национална култура представља извориште на чијем темељу се гради и развија стратешка култура као приступ спољнополитичким питањима.

Како истиче Хофстед (Geert Hofstede), национална култура представља „ментално програмирање: образац мишљења, осећања и деловања које свака особа стекне у детињству и примењује кроз читав живот“ (Hofstede, 2001: 23). Према Јанићијевићу „национална култура се може дефинисати као скуп претпоставки, веровања и вредности које деле припадници једне националне заједнице и који битно одређују њихово разумевање света, као и понашање у њему“ (Јанићијевић, 2004: 14). Наведена одређења националне културе указују да специфична историја, култура, митологија и филозофија једне нације чине основу за разумевање света и деловање у њему. На основу сличних размишљања, теоретичари међународних односа претпоставили су да специфичности националне културе граде јединствену стратешку културу, као визију и праксу спољне политике. Дакле, национална култура обликује „перцептуална сочива“ кроз која се опажа природа међународних односа.

Концепт стратешке културе у науку међународних односа увео је Џек Снајдер, представник неокласичног реализма. ${ }^{32}$ Примена концеп-

32 Неокласични реализам представља правац који је настао на основама неореализма, али настоји да превазиђе недостатак Волцове теорије међународне политике, која у потпуности занемарује спољне политике држава. У прецизирању истраживачког фокуса неокласичног реализма, Џефри Таљаферо истиче: 
та стратешке културе везује се за Снајдеров покушај интерпретирања совјетске нуклеарне доктрине. Он сматра да овај концепт превазилази недостатке тада актуелних и доминантних теоријских приступа и парадигми, превасходно неореализма и његових кључних концепата. Наиме, Снајдер критикује схватање теоретичара да постоји „природна логика која је инхерентна оружју за масовно уништење“, а која постаје јасна сваком ко размотри питање употребе овог оружја. Погрешно је схватање да слична ограничења која оружје за масовно уништење намеће Совјетима и Американцима подразумевају и да ће совјетска доктрина бити истоветна америчкој (Snyder, 1977: 6-7). Насупорт томе, Снајдерова главна претпоставка јесте да ни америчке ни совјетске доктрине нису лишене културолошког утицаја. Оне су развијене у различитим историјским, организационим и политичким контекстима, у одговору на различита ситуациона и технолошка ограничења. Према томе, Снајдер сматра да је корисно сагледати совјетско стратешко размишљање као својеврсну „стратешку културу“. Као резултат процеса социјализације, скуп општих веровања, ставова и образаца понашања, узимајући у обзир и нуклеарну стратегију, достигао је стање полутрајности, што га смешта на ниво „културалног“ уместо на саму политику.

Ставови се могу променити као последица промене у технологији или међународном окружењу. Ипак, нови проблеми не бивају процењени објективно, већ радије кроз „перцептуална сочива“ стратешке културе (Snyder, 1977). Снајдер указује на утицај националне културе на обликовање ставова и веровања у односу на питања која се тичу чак и употребе силе у спољној политици. Тачније, национална култура представља идеациону основу анализе спољнополитичких процеса и догађаја. Управо на овом нивоу Снајдер идентификује концепт стратешке културе, као сйавове у йоїлеgу йримене силе. Када ставови у погледу примене силе, креирани посредством националне културе, достигну стање релативне трајности, они добијају оквир у виду стратешке културе.

Према томе, Снајдер указује да идентификовање историјских и организационих фактора развоја омогућава да се путем приступа стратешке културе објасни порекло и трајна виталност ставова и понашања, која би у супротном могла бити сагледана од стране америчких посматрача као „загонентна, задрта или чудна“ (Snyder, 1977). ${ }^{33}$ Интелектуална историја

\footnotetext{
„Неокласични реализам тежи да објасни зашто различите државе (или чак иста држава у различитим временским периодима) предузимају специфичне стратегије у међународној арени“ (Taliaferro, 2000: 133-134). 33 Кључна разлика међу стратешким културама ове две стране почива на значају који придају унилатералној, у односу на кооперативну, стратегију ограничавања штете. Надмоћ совјетске мисли по овом питању показује склоност ка унилатералном приступу ограничавања штете путем неограниченог контранапада (Snyder, 1977).
} 
совјетске стратешке мисли и осећај за политички и организациони контекст одбрамбеног одлучивања, пружају основу за разматрање совјетских ставова по питању нуклеарног наоружања (Snyder, 1977). У погледу одређења концепта стратешке културе, Снајдер наводи да „стратешка култура може бити дефинисана као укупан скуп идеја, условљених емоционалних одговора и образаца уобичајеног понашања, које су чланови националне стратешке заједнице акумулирали кроз обуку или имитацију и које деле међусобно у односу на нуклеарну стратегију“. Дакле, фокус је на целини ставова и схватања који наводе и ограничавају мисао о стратешким питањима, утичу на начин њиховог формулисања и постављају дискурс и концептуалне параметре стратешке дебате. Совјетска стратешка мисао формулисана је кроз сучељавање са јединственим проблемима у специфичном окружењу, стога ће и совјетска стратешка култура садржати одређене елементе који се могу посматрати као јединствени (Snyder, 1977: 9).

Снајдер сматра да сагледавање свих фактора који су утицали на развој једне нације, тачније, који одређују њен културни и историјски идентитет, омогућава идентификовање стратешке културе, као перспективе са које нација приступа спољнополитичким питањима. Дакле, овај концепт узима у обзир специфичну историју, традицију, религију и филозофију као кључне факторе који одређују приступ спољној политици у смислу питања рата, сарадње и употребе силе.

\section{Прва генерација концейтиуализације}

Аутор који је захваљујући својим академским радовима заузео кључну позицију у разради и одбрани приступа прве генерације у концептуализацији стратешке културе јесте Колин Греј (Colin S. Gray). Поред Снајдера, Греј се убраја у ред главних представника прве генерације, а његова теза да „стратешка култура пружа контекст за разумевање, пре него за објашњење узрочности“, представља фундаменталну претпоставку прве генерације (Gray, 1999b: 49). Управо се ова теза јавља као кључна тачка спорења Греја и Џонстона. Наиме, Греј сматра да овај концепт даје контекст, оквир за разумевање одређеног понашања, али не и објашњење узрочно-последичне везе стратешке културе и понашања. У монографији „Нуклеарна стратегија и национални стил“ (Nuclear strategy and national style) он одређује концепт наводећи следеће: „стратешка култура се састоји од социјално конструисаних и пренетих претпоставки, навика, традиције, и преферираних метода деловања - то јесте, понашања 
- који су мање или више специфични за одређену географски засновану безбедносну заједницу“ (Gray, 1986: 28). Грејево поимање стратешке културе аналогно је Снајдеровом, наиме, он сматра да корен стратешке културе представљају специфична национална култура и традиција друштвене заједнице.

Специфичности националне културе, историје и образаца понашања не морају нужно водити према успостављању искључиво једне стратешке културе. Напротив, Греј сматра да једна заједница не мора бити монолитна, већ може имати неколико стратешких култура. Стратешка култура ће се вероватно испољити кроз стратешко понашање, мада не у механицистичком или детерминистичком смислу. Свака особа која руководи стратегијом може у мањој или већој мери интернализовати одређену културу или више њих. Поред тога, стратешка култура обезбеђује контекст за догађаје и понашање, контекст значења не само „изван“ или „тамо негде“, већ оквир веровања, карактера и навика, чији интегрални део чине људи (Gray, 1999a: 28). Греј уочава да једна нација може имати неколико стратешких култура, не нужно и искључиво само једну, доминантну. Такође, утицај стратешке културе на понашање није могуће сагледати кроз призму детерминистичко-механицистичког приступа.

Поред Снајдера и Греја, неопходно је поменути и Керија Лонгхрста (Kerry Longhurst), који одређује стратешку културу као „карактеристичан скуп веровања, ставова и пракси у односу на употребу силе, који су неговани од стране колектива и настају постепено током времена, кроз јединствен историјски процес. Стратешка култура је постојана током времена, настојећи да надмаши еру свог првобитног постанка, иако није стална или статична карактеристика“. Тако да ставови, вредности или праксе употребе силе чине стратешку културу једне нације (Longhurst, 2018: 17). ${ }^{34}$ Налик Снајдеру и Греју, Лонгхрст истиче да се стратешка култура формира кроз историјско искуство развоја колектива, као и да има битан утицај на формулисање спољне (безбедносне) политике једне државе.

Према Лонгхрсту стратешка култура обухвата три елемента. Прво, постоје дубљи, основни елементи, који се називају йемељним (foundational elements) и своје порекло воде из првобитне или формативне фазе. Темељни елементи укључују основна веровања у односу на употребу силе,

\footnotetext{
34 Када је реч о променама стратешке културе, Лонгхрст разликује две врсте, „фино подешавање“ (fine-tuning) и „фундаменталне“ промене. Прва врста се чешће дешава и подразумева да се стратешка култура у новим ситуацијама фино подешава или прилагођава кроз преправљена становишта безбедносне политике, како би се подударала са темељним вредностима. Када је реч о фундаменталним променама, оне су много већи феномен, дешавају се када су последице неких догађаја толико снажне да анулирају постојећу стратешку културу и утичу на формулисање нових темељних вредности, што води формулисању нових политика и праксе (Longhurst, 2018: 18).
} 
чине срж стратешке културе и веома су отпорни на промене. Проширење ових темељних елемената јесу видљиве манифестације стратешке култуpe, у виду дуготрајних политика и пракси, које се односе и примењују у односу на суштину стратешке културе, а према спољашњем окружењу, обезбеђујући канале значења и примене. Ови аспекти стратешке културе се називају реїулатиорним йраксама (regulatory practices), и оне су мање отпорне на промене. Средишњи елемент између претходно поменута два јесу сииановишйа безбеgносне йолитиике (security policy standpoints). Реч је о тренутним, широко прихваћеним интерпретацијама о томе како темељне вредности промовисати кроз политику, на начин да одреде преференције у погледу избора адекватне политике (Longhurst, 2018: 17).

\section{Друга генерација концеййуализације}

Утемељивач приступа друге генерације у концептуализацији стратешке културе је Бредли Клејн (Bradley S. Klein). У истраживању које је спровео, Клејн се фокусира на проучавање реторике елите, јер сматра да она има за циљ легитимацију војних активности држава. Према његовом становишту, стратешка култура укључује „разноврсне приступе насиљу и начине на који државе могу легитимисати употребу насиља против наводних непријатеља ... истраживање стратешке културе је истраживање културне хегемоније организованог државног насиља“ (Klein, 1988: 135). Дакле, Клејн сматра да је стратешка култура наметнута од стране владајуће елите, и као таква рефлектује њихове интересе у погледу спољнополитичких активности.

Према Клејну, постоје две јасне поенте у концепту стратешке културе. Прва поента је „историзовати оно што је имплицитно садржано у реалистичким теоријама хегемоније“, а друга, „учинити опипљивом политичку продукцију хегемоније артикулисану на теоретском нивоу по Грамшијској концепцији хегемоније“ (Klein, 1988: 136). Такође, Клејн истиче да је неопходно „третирати војну стратегију као културну праксу“. Аутор доводи стратешку културу у непосредну везу са војном стратегијом, али наглашава да је стратешка култура више од тога. Она није заснована искључиво на технолошкој инфраструктури и војном сектору, већ превасходно на „политичким идеологијама јавног дискурса које помажу у одређивању ситуација као достојних за војно учешће“. Наведено значи да стратешка култура умногоме зависи од геополитичког положаја одређене државе и њених односа са савезницима и противницима (1998: 136). Према његовом схватању, стратешка култура укључује војну 
стратегију, чија примена зависи од доминантног идеолошког дискурса наметнутог од стране владајуће елите. Његово становиште у потпуности занемарује приступ аутора прве генерације, који наглашавају да стратешка култура настаје као резултат историјског процеса, артикулацијом вредности и норми једне друштвене заједнице.

Клејн сматра да стратешка култура настаје из мреже међународних пракси, како политичких тако и економских, које ограничавају опсег активности једне државе. Ова ограничења утврђују оквир у којем доносиоци одлука дефинишу спољну политику (Klein, 1988). Дакле, стратешка култура не произлази само из доминантног идеолошког дискурса владајуће елите, већ је одређена, тачније ограничена међународним праксама и обрасцима понашања који се сматрају прихватљивим.

Поред Клејна, у ред аутора друге генерације сврстава се и Едвард Лок (Edward Lock). Лок у свом раду полази од детаљне анализе Клејновог становишта, наводећи да нас Клејнова концепција стратешке културе усмерава да се запитамо како стратешка култура служи да конституише одређено стратешко понашање као смислено, али и како стратешко понашање служи да конституише идентитет безбедносних заједница. Стратешко понашање се према Клејну схвата као место на којем стратешка култура делује, али и место на којем се производи. Импликације овог разумевања односа између културе и понашања су значајне. Лок даље наводи да „уместо да узимамо здраво за готово, наизглед природно постојање безбедносних заједница (посебно држава) и питамо се како атрибут одређене заједнице (њена стратешка култура) утиче на њено понашање, говоримо у корист испитивања стратешких пракси које служе да конституишу заједнице и односе између њих“. Такав приступ нуди практичне користи у смислу већег уважавања политике стратегије и поседује већи критички потенцијал од постојећих приступа (Lock, 2010: 4). Према Локовом схватању, стратешко понашање би требало да буде центар интересовања и проучавања аутора који се баве стратешком културом, јер оно не само да представља исход стратешке културе, већ истовремено системом повратне спреге гради стратешку културу.

У анализи становишта аутора прве и треће генерације, Лок увиђа недостатке који га опредељују за приступ друге генерације. Према његовом схватању, главна мана је занемаривање начина на који се стратешка култура производи. Иако је становиште Бредлија Клејна запостављено, представља потенцијално решење за мањкавости доминантних приступа. Лок одређује концепт на начин да „стратешка култура обликује политички процес кроз који политички или војни лидери доносе одлуке 
о употреби војне силе у датој ситуацији“ (Lock, 2010: 19). Политичке и војне елите се постављају као носиоци стратешке културе, посредством које легитимизују употребу силе у односу на конкретну ситуацију.

Друга генерација концептуализације стратешке културе, представљена у раду Бредлија Клејна, према Локовом мишљењу пружа велике могућности за објашњење начина конституисања стратешке културе. Овај приступ се дистанцира од трагања за коренима стратешке културе и идентитета једне заједнице и окреће према анализи пракси које утичу на изградњу социјалних структура. Тачније, стратешка култура не остаје заувек у облику формираном у развојном периоду заједнице, већ се мења и као таква константно делује на чланове заједнице. Стога, уместо схватања да заједнице „природно“ поседују стратешку културу, треба истражити начин на који праксе везане за употребу војне силе служе реконституисању колективних идентитета и разумевању значења и употребе стратегије (Lock, 2010).

Суштински, аутори других праваца су погрешно подразумевали постојање природне, стабилне и јединствене безбедносне заједнице која поседује јединствену стратешку културу. Такав приступ игнорише конструисану природу колективних идентитета и стратешке културе, игноришући везу ова два феномена. Друга генерација указује на то да постојање дуготрајних образаца у стратешком понашању мора бити истражено, а не само подразумевано (Lock, 2010).

Укратко, теорија стратешке културе друге генерације нас позива да размотримо два општа питања. Прво, како то да одређено схватање колективног идентитета заједнице, однос према другим заједницама и употреба војне силе бивају артикулисани, док друга схватања не? Друго, које последице произлазе из артикулације одређеног разумевања ових централних питања? Стратешка култура треба да се фокусира на анализирање како одређена друштвена структура (стратешка култура) обликује садржај и значење стратешког дискурса, као и које импликације произлазе из примене тог посебног дискурса (Lock, 2010). Дакле, аналогно Клејну, Лок изједначава значај дискурса и праксе у истраживању стратешке културе. 


\section{Трећа генерација концеййуализачије}

Аутор који је поделио концептуализацију стратешке културе на три генерације, Алистер Џонстон, у монографији „Културни реализам: Стратешка култура и велика стратегија у кинеској историји“ (Cultural Realism: Strategic Culture and Grand Strategy in Chinese History), из 1995. године, применио је концепт стратешке културе у анализи кинеске стратегије током владавине династије Минг. Иако не посвећује довољно пажње питању извора стратешке културе, Џонстон наводи да она води порекло од филозофске мисли и писаног као и искуственог наслеђа (Johnston, 1995а: 29). Начин идентификовања стратешке културе Кине потврђује Џонстоново ослањање на писану традицију. Он одређује стратешку културу наводећи следеће:

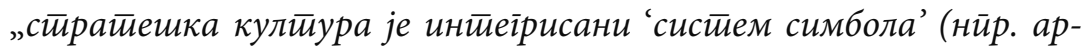

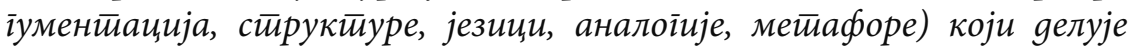

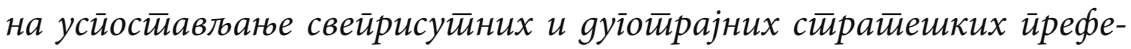
ренција формулисаюем концейайа улоіе и ефикасностии војне силе у међуяржавним иолитиччким йитианима и обавија ове концейције са

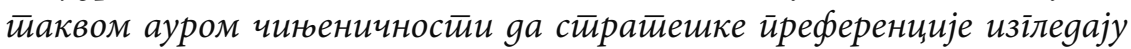
јединсиивено реалистиччне и ефикасне“.

Конкретно, стратешка култура као сисием симбола састоји се од основних претпоставки о уређености стратешког окружења, то јесте, о улози рата у људским односима (било да је то неприродно или неизбежно), о природи противника и претњи коју он представља (нулта сума или варијабилна сума) и о ефикасности употребе силе (способност контроле исхода, елиминисања претње и услови под којима је корисно применити силу). Заједно ова три елемента чине централну парадигму стратешке културе (1995a: 33-47). ${ }^{35}$ Наведена три елемента уједно представљају кључне варијабле у истраживању стратешке културе према Џонстоновом становишту.

У академском раду из 1995. године „Размишљање о стратешкој култури“ (Thinking about strategic culture), Џонстон поново наглашава изворе стратешке културе. Наиме, различите државе имају различите доминантне стратешке преференције које су укорењене у раним или изворним искуствима државе и под утицајем су филозофских, политич-

35 Везано за корист концепта стратешке културе, Џонстон истиче да би се кроз адекватну примену анализе стратешке културе могло помоћи креаторима политике да успоставе исправније и емпатичније разумевање тога како различити актери опажају „игру“ у међународној политици. Лоше спроведена анализа може појачати стереотипе у вези са предиспозицијама других држава и затворити политичке алтернативе као непримерене за суочавање са одређеном стратешком културом (Johnston, 1995a: 63-64). 
ких, културних и когнитивних карактеристика државе и њених елита (Johnston, 1995b: 34). Проблем који Џонстон идентификује у концептуализацији стратешке културе јесте укључивање готово свих елемената, од технологије и географије до идеологије и образаца понашања у „аморфни концепт стратешке културе“, чак иако те варијабле могу бити одвојена објашњења за стратешке одлуке. То је оставило мало простора за нестратешка културална објашњења понашања. Као резултат тога, у истраживању је преовладао механицистичко-детерминистички приступ, који је водио закључку да постоје сасвим јасне и једноставне разлике у стратешким културама различитих држава. Један од проблема јесте и питање извора стратешке културе, наиме, нејасно је на које изворе треба обратити пажњу, као и које аналитичке методе би требало користити да би се откриле дубље структуре стратешке мисли од симболичких до инструменталних елемената, затим како се стратешка култура преноси кроз време и како утиче на понашање (1995b: 38).

Као кључну ствар Џонстон истиче потребу за конструисањем строжег одређења концепта стратешке културе, које јасно спецификује обим и садржај, објекат анализе, историјски период из којег је изведен и методе за извођење стратешке културе из ових објеката (Johnston, 1995b: 39). Стратешка култура јесте „систем симбола“, односно идеја и веровања две врсте. Прва врста обухвата „основне претпоставке“ о уређењу стратешког окружења, односно, улози рата у људској цивилизацији, природи непријатеља и ефективности употребе силе. Друга обухвата идеје и веровања на „оперативном нивоу“, у вези са питањем: „које су стратешке опције најефективније за суочавање са претњама из окружења“. Ниво преференција по питању акција представља почетак непосредног деловања стратешке културе на понашање (1995b: 43-44). Претпоставке о спољнополитичком окружењу, засноване на поимању рата, других држава и употреби силе, чине темељ конструисања и примене стратегије у односу на окружење, догађај или ситуацију. Џонстон сматра да је предност ове генерације избегавање детерминизма прве генерације (Johnston, 1995b). Закључује да у литератури постоје различита поимања стратешке културе, према једном „историјски и културално укорењени концепти циљева и средстава ратовања ограничавају стратешке изборе одлучујућих елита, како тврде прва и трећа генерација, или не ограничавају, како тврди друга генерација“ (Johnston, 1995b: 43). Приступ треће генерације, оличен у Џонстоновом становишту, настоји да применом позитивистичког приступа раздвоји стратешку културу и стратешко понашање, са циљем да укаже на непосредну и недвосмислену узрочно-последичну везу. 


\section{Дебата Греј - Џонстон}

Као што је већ наведено, неколико радова Колина Греја и Алистера Џонстона, представника прве и треће генерације, реализма и социјалног конструктивизма, познато је у академској литератури као „Дебата Греј - Џонстон“. Ова дебата превасходно представља спорење у вези са методолошким приступом у истраживању стратешке културе. Греј као кључну Џонстонову грешку истиче раздвајање културе и понашања, као независне и зависне варијабле, како би указао на утицај прве на другу. Његов позитивистички приступ, којим настоји да укаже како културни контекст утиче или не утиче на област деловања, има смисла. Греј истиче да са методолошког гледишта Џонстон није начинио грешку, ипак, стратешка култура није „тамо негде“ већ са нама, тако да „ми, наше институције и понашање смо контекст" (Gray, 1999b: 53). Како Греј наводи, Џонстон је критиковао његов приступ као детерминистички, а узрок види у томе што је он комбиновао стратешке идеје и понашање у мери да је његово становиште таутологија и немогуће за емпиријско тестирање (Gray, 1999b). Греј се противи Џонстоновом раздвајању стратешке културе и понашања, будући да култура као таква није феномен који је могуће посматрати и проучавати кроз призму позитивистичког приступа. Наиме, утицај културе није могуће сагледати у механицистичко-детерминистичком смислу, који би подразумевао да одређени скуп вредности, претпоставки и норми непосредно условљава одређене обрасце понашања у спољној политици.

Дакле, Грејев методолошки приступ концепту стратешке културе супротставља се Џонстоновој тези о непосредној узрочно-последичној вези стратешке културе и понашања. Према Греју, исправнија је теза да култура обликује процес дефинисања стратегије и њеног испуњења, без обзира колико је стварни избор сродан апстрактним и идеализованим културним преференцијама (Gray, 1999b). Греј сматра да је свако понашање одређено културом, тачније, има одређени културни контекст који треба разумети. Како наводи, суштину спорења и његове дебате са Џонстоном чини питање за шта је потребан, односно која је суштина концепта стратешке културе? Џонстон је више фокусиран на објашњење неког понашања кроз призму стратешке културе и на тој основи формулисане узрочно-последичне везе културе и понашања, док Греј акценат ставља на контекст, разумевање онога што неко понашање значи у датом културном контексту (Gray, 1999b). Разлике у методолошком приступу стратешкој култури воде и различитим циљевима које аутори постављају, па тако позитивистички приступ омогућава Џонстону 
да успостави узрочно-последичну везу између стратешке културе и понашања. Са друге стране, Грејов историјски приступ дијаметрално је супротан позитивизму Џонстона - стратешка култура даје контекст за понашање, које не мора нужно представљати рефлексију вредности и норми стратешке културе.

Према Џонстону, грешка аутора прве генерације јесте схватање о постојању једне, трајне и доминантне стратешке културе у оквиру друштва. Пре ће бити да бројни „инпути“ продукују неколико стратешких култура, које могу бити и контрадикторне. Осим тога, аутори прве генерације нису разматрали могућност раздвајања стратешке културе и понашања (Johnston, 1995b). Џонстон сматра да постоји једносмерна и непосредна узрочна веза од стратешке културе, као независне варијабле, у односу на понашање, као зависне варијабле. У приступу треће генерације, којој и сам припада, Џонстон истиче тежњу ка ригорозној али и еклектичној концептуализацији, чиме срж ове школе чини покушај да се доношење стратешких одлука (понашање) посматра као зависна варијабла (Johnston, 1995b). Суштина дебате међу ауторима прве и треће генерације теоретичара стратешке културе јесте питање да ли референти објект изучавања треба да буде коришћен за „разумевање“ или за „објашњење“ стратешког понашања држава у безбедносним и одбрамбеним односима. Џонстон посматра стратешку културу као потенцијално важну независну варијаблу за објашњење понашања као идеационог миљеа који ограничава изборе у понашању. За разлику од њега, Грејево становиште узима „културу као контекст“, који обухвата и прожима понашање политичких актера (Meyer, 2005).

Дакле, језгро дебате Греја и Џонстона јесте питање улоге понашања у концепту стратешке културе, тачније, да ли оно треба бити посматрано као део концепта или изоловано у односу на концепт стратешке културе. Греј сматра да готово свако понашање произлази из културе и стога је несумњиво контекстуализовано, а акценат би требало да буде на разумевању самог контекста у коме понашање настаје и добија своју форму. Са друге стране, Џонстон раздваја понашање од концепта стратешке културе, коју посматра као независну варијаблу, са циљем да измери њену узрочну моћ у односу на понашање једне државе, које узима као зависну варијаблу. Утицај стратешке културе на понашање одвија се на начин да она одређује ограничен или рангирани скуп стратешких преференција. Предност оваквог методолошког приступа, Џонстон објашњава чињеницом да овај приступ пружа могућности научне провере или доказивања утицаја стратешке културе на понашање. Утврђивање узрочно-последичне везе ових феномена омогућава и предикцију 
спољнополитичког понашања држава. Са друге стране, главни недостатак прве генерације састоји се управо у недостатку научне верификације претпоставки у вези са утицајем стратешке културе на понашање. Култура је контекст сваког понашања, али не и узрок, стога је успостављање узрочне везе ових феномена тешко, јер су и они природно неодвојиви.

На основу дебате Греја и Џонстона али и приказаних становишта аутора три генерације у концептуализацији стратешке културе, могуће је идентификовати неке од сличности и разлика међу њиховим становиштима, које су приказане у табели 1. Табела 1. Карактеристике становишта аутора три генерације у
концептуализацији стратешке културе

\begin{tabular}{|c|c|c|c|}
\hline Генерације & Прва & Друга & Трећа \\
\hline $\begin{array}{c}\text { Теоријски } \\
\text { приступ }\end{array}$ & $\begin{array}{c}\text { Реализам и } \\
\text { социјални } \\
\text { конструктивизам }\end{array}$ & $\begin{array}{c}\text { Социјални } \\
\text { конструктивизам }\end{array}$ & $\begin{array}{c}\text { Социјални } \\
\text { конструктивизам }\end{array}$ \\
\hline Аутори & $\begin{array}{c}\text { Џек Снајдер, Колин } \\
\text { Греј, Кери Лонгхрст }\end{array}$ & $\begin{array}{c}\text { Бредли Клејн, } \\
\text { Едвард Лок }\end{array}$ & Алистер Џонстон \\
\hline $\begin{array}{c}\text { Извори } \\
\text { стратешке } \\
\text { културе }\end{array}$ & $\begin{array}{c}\text { Историја, култура, } \\
\text { географија, } \\
\text { технологија итд. }\end{array}$ & $\begin{array}{c}\text { Пискурс елите и } \\
\text { спољнополитичка } \\
\text { пракса }\end{array}$ & $\begin{array}{c}\text { Историја, култура, } \\
\text { филозофија, } \\
\text { традиција, итд. }\end{array}$ \\
\hline Варијабле & $\begin{array}{c}\text { Идеационе и } \\
\text { материјалне }\end{array}$ & $\begin{array}{c}\text { Идеационе и } \\
\text { материјалне }\end{array}$ & Идеационе \\
\hline
\end{tabular}

(Извор: аутор)

У датој табели аутори су сврстани према генерацијама којима припадају и теоријском приступу, а затим су наведени извори стратешке културе и варијабле које су они идентификовали у својим становиштима. На основу приказане табеле увиђа се сличност прве и треће генерације у погледу извора стратешке културе, док друга генерација у потпуности занемарује дате факторе (историју, културу, филозофију, итд.). Осим тога, питање варијабли које омогућавају идентификовање и дефинисање стратешке културе остаје кључна тачка спорења између аутора три генерације. Иако прва и трећа генерација придају значај сличним идеационим варијаблама, приступ треће генерације не препознаје материјалне варијабле. Са друге стране, приступ друге генерације идеационе факторе идентификује у политичком дискурсу друштвених елита, што чини есенцијалну карактеристику овог приступа и кључну разлику у односу на идеационе факторе које идентификују аутори прве и треће генерације. 


\section{Закључак}

На основу приказаних становишта аутора који су тематизовали концепт стратешке културе, утврђена је сличност у погледу тога да овај концепт у основи почива на националној култури одређене нације. Национална култура, у складу са својим специфичностима (историја, традиција, филозофија, религија, географија, итд), гради стратешку културу као својеврстан приступ спољној политици. Тачније, стратешка култура, као приступ спољној политици, јавља се као исход културално утемељеног поимања рата и употребе силе. Одговор на дата питања формира „перцептуална сочива“, кроз која се стратешке реалности опажају. Услед тога се идентична стратешка реалност опажа на различит начин, који проистиче и из карактеристика стратешке културе. Дакле, национална култура дефинише оквир развоја стратешке културе, рефлектујући културни образац нације на спољнополитички аспект државног деловања.

Како стратешка култура има своје корене у историјском и културном наслеђу једне нације, ове дубоко укорењене карактеристике одређују перцепцију неког догађаја или ситуације, али и поступање, тиме дајући јединствену карактеристику спољнополитичком деловању једне државе. У односу на ово схватање, заједничко за ауторе прве и треће генерације, дијаметрално супротно стоје становишта аутора друге генерације, који у потпуности занемарују историјске и културне претпоставке развоја стратешке културе. Стратешка култура, према њиховом схватању, артикулисана је идеолошким дискурсом владајуће елите, која има за циљ да легитимизује примену силе. Са друге стране, фундаментална несагласност и спорење у вези са концептом стратешке културе подразумева методолошко питање посматрања стратешке културе као независне варијабле и понашања као зависне варијабле. Представници прве генерације заговарају приступ који негира могућност проучавања стратешке културе у позивитистичком маниру. За њих, покушаји да се утврди јасна и непосредна узрочно-последична веза између стратешке културе и понашања нису оствариви. Култура даје контекст, оквир за одређено понашање, али не представља и његов непосредни узрок, и према томе циљ примене концепта јесте „разумевање“ одређеног понашања у оквиру културалног контекста. Са друге стране, позитивистички приступ треће генерације настоји да „објасни“ спољнополитичко деловање кроз призму стратешке културе, успостављањем јасне узрочно-последичне везе културе и понашња. 
Културална димензија међународних односа дуго времена је била под сенком акултурално и аисторијски утемељених приступа. Концепт стратешке културе увео је у науку међународних односа перспективу анализе спољнополитиког деловања засновану на темељу историјског и културног идентитета нација. На тај начин је подручје стратегије спољнополитичког деловања идентификовано као иманентна карактеристика националне културе. 


\section{ЛИТЕРАТУРА}

Enloe, C. \& Zalewski, M. (1995). „Questions of Identity in International Relations“. In: Booth, K.\& Smith, S. (Eds). International Relations Theory Today. Polity Press, 279-305.

Gray, C. S. (1999a). Modern strategy. Oxford: Oxford University Press.

Gray, C. S. (1999b). Strategic culture as context: the first generation of theory strikes back. Review of international studies, 25(1), 49-69.

Hofstede, G. (2001). Culture's consequences: Comparing values, behaviors, institutions and organizations across nations. New York: Sage publications.

Janićijević, N. (2013). Organizaciona kultura i menadžment. Beograd: Ekonomski fakultet.

Johnston, A. I. (1995a). Cultural realism: Strategic culture and grand strategy in Chinese history. Princeton: Princeton University Press.

Johnston, A. I. (1995b). Thinking about strategic culture. International security, 19(4), 32-64.

Klein, B. S. (1988). Hegemony and strategic culture: American power projection and alliance defence politics. Review of international studies, 14(2), 133-148.

Lock, E. (2010). Refining strategic culture: return of the second generation. Review of International Studies, 36(3), 685-708.

Longhurst, K. (2018). Germany and the use of force. Manchester: Manchester University Press.

Meyer, C. O. (2005). Convergence towards a European strategic culture? A constructivist framework for explaining changing norms. European journal of international relations, 11(4), 523-549.

Snyder, J. L. (1977). The Soviet Strategic Culture. Implications for Limited Nuclear Operations (Vol. 2154, No. AF). Santa Monica: RAND Corporation.

Taliaferro, J. W. (2000). Security Seeking under Anarchy: Defensive Realism Revised. International Security, 25(3), 128-161.

Waltz, K. (1979). Theory of International Politics. Boston: Addison-Wesley Publishing Company

Weber, C. (2010). International Relations Theory: a Critical Introduction. London: Routledge.

Wendt, A. (1999). Social Theory of International Politics. Cambridge: Cambridge University Press. 


\title{
STRATEGIC CULTURE CONCEPT IN SECURITY STUDIES
}

\author{
Dušan Kesić, PhD Student \\ University of Belgrade, Faculty of Security Studies
}

\begin{abstract}
Summary
The concept of strategic culture emerged in the late 1980s. The author who founded this concept in security studies, Jack Snyder, used the concept of strategic culture for interpretation of Soviet nuclear doctrine in the Cold War period. The conceptualization of strategic culture has played a dominant role in two theoretical approaches to the study of security, realism and social constructivism. The aim of this paper is to show the way of conceptualization of strategic culture in security studies, more precisely, within the realism and social constructivism schools. The realization of this goal implies the attempt to present the most relevant findings of the authors who have discussed the concept of strategic culture in their works. The conceptualisation view is divided into three generations of authors, while the works of the first and third generation authors, Colin Gray and Alistair Johnston, represent the "core" of methodological disputes regarding the concept of strategic culture. The essence of the concept of strategic culture is that national culture is a foundation that embodies and builds a unique approach to foreign policy, based on a culturally understanding of war and the use of force.
\end{abstract}

Keywords: strategic culture, national culture, realism, social constructivism. 